\title{
Getting to grips with the public trust doctrine in biodiversity conservation: A brief overview
}

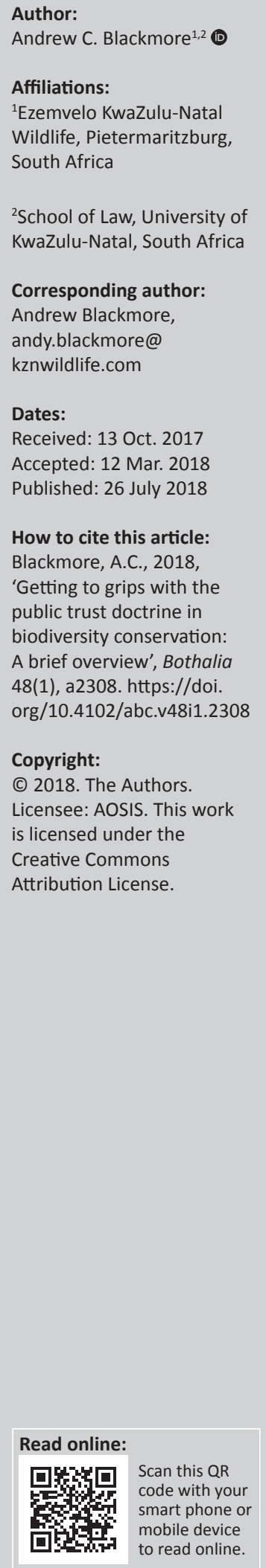

Author:

Affiliations:

Ezemvelo KwaZulu-Natal

Wildlife, Pietermaritzburg

${ }^{2}$ School of Law, University of

Corresponding author:

Andrew Blackmore,

andy.blackmore@

Dates:

Received: 13 Oct. 2017

Accepted: 12 Mar. 2018

How to cite this article:

Blackmore, A.C., 2018,

'Getting to grips with the

biodiversity conservation:

A brief overview', Bothalia

48(1), a2308. https://doi.

Copyright:

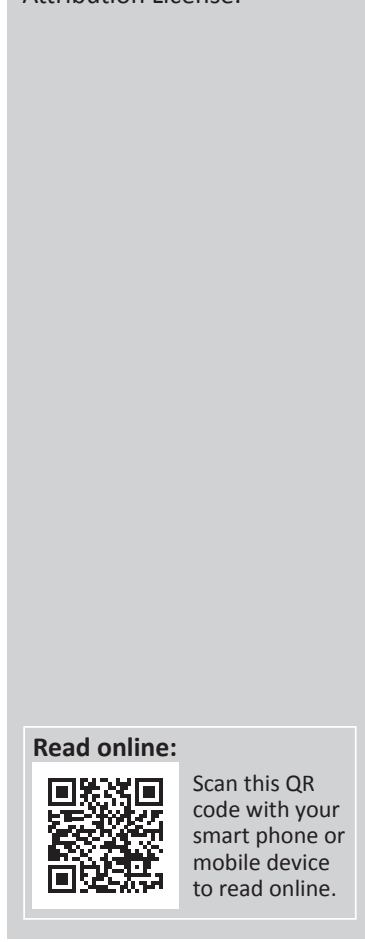

The explicit incorporation of the public trust doctrine into South Africa's Bill of Rights in South Africa's Constitution, and its subsequent codification into the country's environmental biodiversity, protected area, water, minerals and heritage legislation, occurred to a large extent without applause or fanfare. It is apparent that in the 20-odd years since the adoption of South Africa's Constitution, the existence and importance of the public trust doctrine within the academic and legal fraternities, bureaucratic decision-making and the courts have largely been overlooked. This observation evokes curiosity about the history and evolution of the doctrine and its meaning and relevance in, at least, the conservation of biodiversity in a South African context. It is concluded that the nature of the application of the public trust doctrine in South Africa remains an enigma, and the development and refinement of this jurisprudence are required. The variable and, in places, conflicting wording of the trust-related provisions in a number of South Africa's environmental statutes suggests that the doctrine and hence the nature of its application was not fully understood by the drafters of the statutes or by the legislature adopting those statutes into law. The public trust doctrine in South African environmental law lies beyond the country's Constitution, and appears to have multiple bloodlines, which dispels the notion that South Africa hermetically imported the concept from a single source. The interpretation and hence the nature of the application of the doctrine in South Africa is likely to be influenced by the country's heritage and hence is likely to vary between the disciplines that constitute South Africa's environmental law.

\section{Introduction}

Section 2 of the National Environmental Management Act (NEMA - 107 of 1998) and Section 3 of both the National Environmental Management Biodiversity Act (NEMBA - 10 of 2004) and the National Environmental Management: Protected Areas Act (NEM:PAA - 57 of 2003), and many other statutes regulating the environment, refer to the state's role of 'trustee' of biodiversity and protected areas. The question arises as to the significance of this legal provision for government officials, regulating the use of biodiversity or managing a protected area, researchers and research institutions and the public at large.

Globally, the public trust doctrine has enjoyed a plethora of definitions. Many of these, and the concomitant understanding of the application of the public trust doctrine, have been based on legislative reasoning and academic arguments and judgements. For example, Professor Joseph Sax described the doctrine as the 'principle purpose of government to promote the interests of the general public rather than to redistribute public goods from broad public uses to restricted private benefit', and argued that the 'central substantive thought' in public trust proceedings is:

$[w]$ hen a state holds a resource which is available for the free use of the general public, a court will look with considerable scepticism upon any government conduct which is calculated either to reallocate that resource to more restricted uses or to subject public uses to the self-interest of private parties. (Sax 1970)

By way of contrast, the Kenyan courts defined the doctrine as the:

State, as trustee, is under a fiduciary duty to deal with the trust property, being the common natural resources, in a manner that is in the interests of the general public. (Waweru 2007)

\section{NEMA holds the doctrine as:}

$[t]$ he environment is held in public trust for the people, [and] the beneficial use of environmental resources must serve the public interest and the environment must be protected as the people's common heritage.

Subsequently, in one of the few South African legal proceedings in which the concept of the public trust was relied upon, Justice Ngcobo stated that the concept of 'sustainable development will 
ensure that socio-economic developments remain firmly attached to their ecological roots and these roots are protected and nurtured so that they may support future socio-economic developments' (Fuel Retailers 2007).

This article seeks to give (1) an overview of the origin of the public trust doctrine as well as its potential evolution within an African context with a view to providing insights into how it may be applied in bureaucratic decision-making to safeguard South Africa's biodiversity and (2) to speculate on the role research and research institutions may play in furthering the understanding and application of the doctrine.

\section{Roman law roots of the public trust doctrine}

The public trust doctrine has its roots in Roman and Roman customary law, and South Africa and several other countries inherited Roman law from its antecedent Anglo-Saxon colonial powers. In its essence, the public trust doctrine is based on the concept that certain components of the natural environment are inherently considered to be res omnium communes and res extra commercium, in that they are common to all and cannot be held in private ownership (e.g. fisheries and waterways) (Feris 2012). This is opposed to res publica, which are commonly held resources which, under certain circumstances, may be held in private ownership by way of res privatae or res singulorum (e.g. the communication frequencies of the electromagnetic spectrum), or res nullius in which an object (e.g. a wild animal) is owned by no one but may become owned by a person taking physical possession (Muir 2016). The distinction between res omnium communes, res publica and res nullius may not necessarily be absolute and constant over time in that the public retains a vested interest (to varying degrees, and depending on the magnitude) in the use and disbursement of components of the natural environment. This is particularly relevant in such circumstances where a natural resource is no longer abundant or the integrity of the resource may be threatened by way of a specific or cumulative use.

The evolution of the public trust doctrine from its Roman roots, and its resultant flexibility in addressing previously unconceived human-induced threats to the natural environment, has been comprehensively demonstrated in the United States (Kundis-Craig 2010). This led to speculation that South Africa (Sand 2014; Takacs 2008; Treves et al. 2017), as well as Brazil, Canada, Ecuador, India, Kenya, Namibia, Nigeria, Pakistan, Swaziland, the Philippines and Uganda (Blumm \& Guthrie 2012), and perhaps other countries, purposefully imported the doctrine, either implicitly or explicitly, from the United States into their respective environmental legal systems.

An analysis of the statutes comprising South Africa's environmental law suggests, however, that there was not a hermetic import and that the public trust doctrine is more likely to have had several origins. Of these, the evolution of the doctrine in Africa and its ultimate influence on South Africa and its fledgling democratic legal system following the end of apartheid in 1994 is probably the most profound.

\section{Development of embedding of the public trust doctrine in African international law}

While not explicitly stated, the probable beginnings of the public trust doctrine in Africa may be traced to the 19th century and the drafting of the Convention of the Preservation of Wild Animals, Birds and Fish in Africa (the 1900 London Convention - British Parliamentary Papers 1900). Recognising the rapid loss of wildlife as a result of both trophy and meat hunting, this Convention endeavoured to form the foundation for the colonial powers' fiducial duties to regulate the indiscriminate consumptive use of wildlife, and to set in place protected areas to conserve representative samples of biodiversity. This Convention never came into force, and was replaced by the 1933 London Convention (The Convention Relative to the Preservation of Fauna and Flora in their Natural State). From a public trust perspective, the hallmark of the 1933 London Convention was the establishment of protected areas, with the founding of the requirement of a system of national parks, as well as the establishment of 'strict natural reserves' as a prime means to safeguard each territory's biodiversity. While embracing the concept that wildlife needed to be conserved for the current and future common good, it also recognised that the protected areas were a key instrument in giving effect to this fiduciary duty. It was for this reason that the Convention required its colonial powers to prohibit (save under exceptional circumstances) the alienation of any part of an established protected area. While the common-sense relationship of this provision to the public trust doctrine is evident, the subtle significance of this provision lies in policy being able to prescribe what is unquestionably considered to fall within the scope res omnium communes or res extra commercium (the public trust entity) and res publica.

Apart from a key focus on wildlife and protected areas, an additional hallmark of the 1933 London Convention was broadening the scope of the public trust duties of the colonial powers to include 'objects of aesthetic, geological, prehistoric, historical, archaeological, or other scientific interest'. The Convention explicitly noted that these environmental values were to be safeguarded for the 'benefit, advantage, and enjoyment of the general public'. The significance of this inclusion in the Convention is the realisation that a greater variety of environmental components required active consideration, management and protection, in order for these to be available for enjoyment by current and future generations. This Convention, therefore, ushered in a growing awareness that the environment is finite and in many respects includes non-renewable components that need to be proactively safeguarded. The now independent African states, under the auspices of the then Organisation of African Unity, adopted the Arusha Manifesto, which was a truly an African statement on the conservation and protection of the continent's natural environment. In his opening address at the launch of the Manifesto, the first prime minister of the then Tanganyika, 
Julius Nyerere, epitomised the core concerns and ultimate purpose of the Manifesto: (1) the inextricable dependence of the health and well-being of Africans on a naturally functioning and sustainably used natural environment and (2) that newly established African governments have an obligation to act as a trustee of their country's wildlife (as an inheritance) for the enjoyment of future generations (IUCN 1961). In so doing, Nyerere and the Arusha Manifesto formally brought the doctrine of public trusteeship into African multilateral environmental jurisprudence. Following the Manifesto's lead, the 1968 Algiers Convention (African Convention on the Conservation of Nature and Natural Resources) further extended the fiduciary duties of the African states to the entire environment by way of the inclusion of edaphic and hydrological considerations.

The Algiers Convention has been recently replaced by the (revised) African Convention on the Conservation of Nature and Natural Resources, which was signed in Maputo in 2003 (the Maputo Convention). The Maputo Convention enhances the trust requirement of its parties to consider and brings marine issues on par with terrestrial biodiversity conservation. In this, parties are obliged to establish, maintain and expand an integrated network of protected areas, as a means to ensure that representative samples of African terrestrial and marine biodiversity are formally protected and safeguarded.

The significance of this history lies not only in 100 years of Africa embracing the fundamental importance of the fiduciary duties of each African state to protect its biodiversity, but also in the extension of the doctrine far beyond its original Roman application to every aspect of each county's natural and cultural environments. The evolution of the doctrine in this multilateral context has also provided a firm foundation for, at least, the African states, and particularly South Africa to bring the doctrine into their respective environmental legislation.

\section{The public trust doctrine in South African environmental law}

The obvious origin of the public trust doctrine is the 'Environmental Right' provided in section 24 of the Bill of Rights in the country's constitution which states that:

\section{Everyone has the right:}

- to an environment that is not harmful to their health or well-being and

- to have the environment protected, for the benefit of present and future generations, through reasonable legislative and other measures that -

- prevent pollution and ecological degradation

- promote conservation

- secure ecologically sustainable development and use of natural resources, while promoting justifiable economic and social development. (SA - Republic of South Africa: Constitution of the Republic of South Africa, Act 1996).
Notwithstanding the existence of this Right, some commentators have suggested that the adoption of the doctrine into South African environmental law was solely by way of a hermetic import of a 'Saxion' interpretation and with that an American-orientated understanding and hence application of the concept (Sand 2014; Takacs 2008; Treves et al. 2017). The significant influence of the development of the doctrine in Africa, as well as its domestic evolution from first principles of the concept, has largely been overlooked. It appears, therefore, that the South African legal provisions relating to the public trust and the concomitant fiduciary duties of government suggest a number of bloodlines of the doctrine. For instance, the stark parallels between the provisions of South Africa's Policy on Environmental Management (Environmental Management Policy 1998) and the Brundtland Report (1987), and concomitantly the 1992 Rio Declaration on Environment and Development and the Convention on Biological Diversity, suggest a strong rooting of the doctrine in Western and global multilateral environmental agreements and international soft-law ideology. In sharp contrast, however, the provisions in specific environmental legislation provided for by the National Environmental Management Act 107 of 1998 (NEMA) suggest a strong rooting of the doctrine in an African multilateral agreement setting. The coastal zone and air quality legislation, however, tend to be more aligned with the original Roman and Roman-Dutch principles, upon which South African law is predominantly based. Furthermore, provisions emulating the public trust doctrine within the legislation regulating water quality and quantity appear to have had a strong Western influence (Blackmore 2018).

Finally, the assumption that South Africa unilaterally imported the well-developed understanding and application of the doctrine from America (Sand 2014; Takacs 2008; Treves et al. 2017) is further countered by the discovery that the doctrine has not been uniformly codified across and, in certain instances, within the various disciplines comprising the environment. The explicit provision of the public trust doctrine in South Africa's National Water Act (36 of 1998) appears to be inconsistent with other key trust-related provisions in the Act. The most profound in this regard is a fiduciary duty of the government to safeguard the minimum requirement of water to ensure the ecological integrity of the country's water bodies. Here the drafters created an exceptionally progressive provision that appears to confer an absolute right to the environment, by way of setting in place the ecological reserve, but they appear to be extremely conservative, if not overly restrictive, in defining the scope of the trust in the Act. Here the fiducial duties of government are limited to 'promoting environmental values', which is in sharp contrast to confirming a 'right' by way of the ecological reserve.

Likewise, South Africa's National Heritage Resources Act (25 of 1999) appears to conflate the responsibility of the trustee and the beneficiaries. These observations suggest that at the time of drafting the components of South Africa's environmental 
legislation, the authors of at least these two statutes, as well as the legislature adopting such into law, may not have had a thorough and cohesive understanding of the public trust doctrine. Furthermore, the nature of the public trust doctrine as codified in the specific environmental Acts provided for in NEMA suggests different origins. NEMA, by way of its founding policy (Environmental Management Policy 1998) and environmental principles, suggests a close affinity with the Brundtland Report and the Rio Declaration, whereas (despite its founding policy, Conservation and Sustainable Use of South Africa's Biodiversity 1997) the NEMBA and the NEM:PAA have a strong affinity with an African origin. Also, as pointed out above, the Integrated Coastal Management Act (24 of 2008) is more closely aligned with the doctrine's Roman roots.

These observations highlight the possibility that as the public trust doctrine is increasingly used, it is likely to evolve its own distinctive character within a South African context.

\section{The public trust doctrine ownership}

The separation between private ownership and what constitutes the public trust entity is complex and often unclear. By seeking the wisdom and guidance of the courts, America has made great strides to clarify this separation within their environmental and legal contexts. Other countries appear to be following suit, particularly in terms of requiring the courts to confirm the core entities of the public trust (Mehta 1997; Minister of Water and Environmental Affairs 2016; Niaz 1996; Waweru 2007). The separation between the biodiversity component of the trust entity and specimens or pieces of natural land has largely remained uninvestigated and hence remains, on the whole, ambiguous. In many respects, this conundrum relates to the separation between what constitutes the public trust and private, communal or government ownership.

In its simplest form, the objective of the state in exercising its fiduciary duties is limited to the realm of trustee of common (res omnium communes or res extra commercium) property, which cannot be extended to ownership or even a vested interest in ownership. While the state may, in certain circumstances, be the property owner, this function remains separate from its overarching trusteeship persona. Thus, exercising its fiduciary duties to safeguard biodiversity and the environment as a whole cannot be extended by government into the realm of private and communal ownership without risking giving effect to unlawful expropriation or takings (Bramley 2011). Irrespective of the circumstances, therefore, exercising a public trust duty cannot encroach on the domain of private ownership (Van der Schyff 2013). Thus, from a public trust perspective, elements that comprise South Africa's biodiversity cannot be part owned privately (or communally) and part owned by the government as the trustee. To do so would conflate the roles of trustee and an owner of a component of biodiversity. Likewise, as with sovereignty, the government cannot use its fiducial duties as a springboard or conduit to take ownership of biodiversity that occurs within the country's borders, even if that biodiversity is considered res nullius. Such separation of fiducial duties and ownership is highlighted by regulations that require all elephant, sovereign to South Africa, to be subjected to a management plan that secures their safety and well-being. The extension of such public trust and sovereignty obligations to unowned wild elephant would be a bridge too far and would be unlawful (Blackmore \& Trouwborst 2018). The separation of 'trustee' and 'ownership' is, however, from a legal perspective, extremely complex and is often transgressed when the government's regulatory power impinges on the legitimate rights vested in ownership (Van der Schyff 2013). This realm of law falls outside the scope of this article, save to stress that privately or publically owned biodiversity, as with other components of the environment, forms part of or comprises the public trust entity. The use of this biodiversity may, therefore, in the public interest be reasonably regulated by government.

\section{Public trust doctrine anatomy}

Irrespective of the definition, or the history within which it evolved, a contemporary understanding of public trust may be reduced to six key components. The division of the trust into these components provides insights not only into the nature of the doctrine, but importantly into how the doctrine is to be applied and researched. The six components are as follows:

- Human health and well-being are inextricably linked to the natural environment and the provision of environmental products and services.

- The environment (the public trust entity) needs to be described and quantified by at least the trustees and known by the beneficiaries.

- Environmental decision-making should not compromise the potential opportunities or health and well-being of others or further generations, and therein the concept of intra- and inter-generational equity is embraced.

- Certain components that constitute the environment cannot be alienated into private ownership or irreversibly lost.

- Trustees of the environment are bound by fiduciary obligations to safeguard the environment and are accountable to the public for decisions taken or not taken.

- There is a clear separation of the roles and responsibilities of the trustee (the government) and the beneficiaries (the people) (Babcock 2015; Blackmore 2014, 2017b; Blumm \& Guthrie 2012; Bruskotter, Enzler \&Treves 2011; Hare \& Blossey 2014; Sagarin \& Turnipseed 2012; Sax 1971; Wood 2013).

These six components make implicit that the fiduciary duties of government are both progressive and retrospective (Blackmore 2014). Thus, in those circumstances where the natural environment has historically been allowed to degrade, or the sustainable-use threshold has been exceeded, through active decisions taken (or by way of indecision), the government retains its fiduciary obligations 
to rehabilitate, remediate and restore that component of the public trust entity has been damaged or lost (Blackmore 2014). The challenge facing government is the recovery of the costs of the restoration from those who caused and benefited from the damage in accordance with the polluter pays principle. In many respects, given the difficulty of unequivocally identifying the responsible person or persons, the cost of the restoration becomes a public burden (Blackmore 2014; Du Plessis 2015; Turnipseed et al. 2012). Notwithstanding this reflection, South African environmental laws, and in particular NEMA, provide a legal opportunity for both the government and, importantly, the public to intercede where the environment and biodiversity are placed at risk (Blackmore 2014).

\section{Application of the doctrine in decision-making}

The National Environmental Management Act obligates all organs of state, and hence the officials therein, to apply the public trust doctrine and other environmental principles when making decisions that concern the environment. Ensuring the application of the public trust doctrine, however, remains a challenge for decision-makers. This observation is particularly relevant in a country like South Africa, where the concept has, for all intents and purposes, been overlooked and biodiversity is rapidly disappearing (Jewitt et al. 2015). The same applies to the general public when questioning whether the public trust doctrine was appropriately applied in a decision taken by a government official or during the review of the decision taken. From a biodiversity perspective, the application of public-doctrine thinking and gaining an understanding of the sensitivity of or risk to the environment may be achieved by applying a framework of probing questions as described in Blackmore (2017a). The purpose of applying guiding questions would be directed at determining the extent or significance of the residual negative impact, after mitigation, on the environment. In so doing, the bureaucrat, legal practitioner, member of the public, user of biodiversity or researcher would be able to gauge whether the integrity of the biodiversity public trust entity is at significant risk or has even been compromised.

Where a decision fails to pass muster, NEMA empowers an individual or an organisation to seek relief from the courts. This is founded on granting people the locus standi to approach the courts in their own or the group's interest, or on behalf of a person or group of persons who are unable to institute legal action (i.e. future generations), in the public interest or in the interest of protecting the environment. Should such litigation prove unsuccessful, the court may waive costs where such action was, inter alia, 'reasonably out of a concern for the public interest or in the interest of protecting the environment'. This concession removes the disincentive caused by the cost of litigation, and therein makes the courts more accessible to people and the public, who have a genuine interest in protecting the environment and ensuring that the country's environmental laws are appropriately implemented and enforced.
Furthermore, NEMA provides protection for whistle-blowers and can seek the assistance of the courts to enforce the country's environmental legislation and to institute a private prosecution in the public's interest or in the interest of protecting the environment, and naturally the biodiversity therein. These provisions of the NEMA affirmatively enable members of the public to perform a monitoring and surveillance function and to approach the courts to intervene in the interests of their rights to have the environment protected where the government has failed to do so. The application of the public trust doctrine in the realm of conservation of biodiversity and the protection of species and habitats invariably encounters emotional, ethical and moral pressures, particularly those emanating from society and its concerned components. The application of the doctrine is also subject to, in particular, short-term political and parochial economic pressures that are often not aligned with the conservation of biodiversity and the safeguarding of the broader natural environment. The challenge placed on government is to find a solution that both conserves biodiversity and promotes human, economic and political well-being in a balanced and transparent manner (McShane et al. 2011).

This challenge is unfortunately frustrated in circumstances where simplifying the understanding of the public trust entity occurs, to the detriment of biodiversity (McShane et al. 2011). This circumstance is demonstrated in the cases of the proposed eradication of the tsetse fly, the selective and intensive breeding of wildlife (Armstrong \& Blackmore 2017) or challenging the integrity of a protected area when such is perceived as a resource or an expedient opportunity for nonconservation-orientated development, like that proposed for Ndumo Game Reserve and Tembe Elephant Park (Blackmore 2014, 2015). The principle of the public trust precludes the government from the arbitrary granting of a capriciously convenient decision, where such a decision would lead to a loss in the value and integrity of the environment and its biodiversity (Blackmore 2015). In such circumstances, a decision of this kind would be considered 'unsustainable' and a moratorium or a 'no-go' or 'no destruction of biodiversity' option, in accordance with the precautionary or risk-averse principle, ought to prevail (Myhr \& Traavik 2002).

\section{Role of research and information in public trust decision-making}

The challenge experienced by the adjudicating official is often seated in whether a proposed use or potential damage to biodiversity would, if granted, cause that component of biodiversity to traverse (at least) its sustainable-use threshold and therein contribute to extinction or a system collapse. It stands to reason, therefore, that decisions taken by an official representing the government must ideally be risk-averse and must be based squarely on a defendable understanding of the conservation status of the component of biodiversity at risk of being damaged. Given the dependence of sound evidence-based decision making on research, a reasonable expectation, if not an obligation, 
is placed on researchers and research institutions to provide robust, accurate and relevant, context-sensitive, independent and unbiased information (Clavero \& García-Bertho 2005; Dicks et al. 2014; Fanelli 2009; Krausman \& Cain 2013; Myhr \& Traavik 2002; Pullin \& Knight 2003; Sarewitz 2004; Van Noorden 2011). The pinnacle of this argument lies in the realisation (by both bureaucrats and researchers alike) that decisions that lead to protection or the erosion of the biodiversity component of the trust entity are likely to persist indefinitely and are, in the case of the extinction of a species or a habitat, usually not realistically reversible (Novacek \& Cleland 2001). The recognition of the accuracy and applicability of research is, therefore, paramount.

The understanding and application of the public trust doctrine, at least in South Africa, suffers from an intrinsic separation from empirical research, which is generally the case with the development of policy and legislation (Singh et al. 2014). As a result, policy and decision-makers place greater reliance on parochial experience and informal or tacit knowledge than on scientific information (Cvitanovic et al. 2014; Nguyen, Young \& Cooke 2017).

For conservation scientists and research institutions to influence conservation and environmental decision making and practices, the onus lies with them to provide an accurate research product, which is context sensitive and which can be easily interpreted in a responsible manner (Blackmore 2017a; Clavero \& Garcia-Berthou 2005; Fanelli 2009; Van Noorden 2011). This observation is particularly relevant in the conservation sector where, when contrasted with other disciplines like health, heuristic research underpinning decision-making is uncommon. The corollary of this circumstance, particularly given the rareness of research on biodiversity-related decision making, is the vulnerability of decisions to perverse research in which 'expedience, falsification, fabrication or misrepresentation of information prevail' (Blackmore 2017a). In addition, given the paucity of investigation into and the reliance on the public trust doctrine in South Africa's biodiversity and environmental decision-making, government officials are at risk of resorting to an undue reliance on a prevailing norm or personal stance, applying an ill-considered opinion of another, or drawing heavily on or remaining inextricably consistent with previous decisions (Johnson \& Graber 2002). Under such circumstances, the information gleaned from perverse research may persist in decision making, even when such research is withdrawn or superseded by more accurate information (Van Noorden 2011).

While the public trust doctrine provides decision-making officials with a powerful mechanism to anticipate and regulate unsustainable use of the natural environment, and in particular with respect to biodiversity (Torres \& Bellinger 2014), its long-term effectiveness can only be guaranteed by way of public surveillance and, with the assistance of the courts, scrutiny of regulatory decisions taken (or failure to be taken), that affect the trust entity. In this regard, it is both appropriate and desirable for researchers and research institutions to package their research in a manner, which emphasises its relevance and is articulated in a way that is understandable by the lay public and the legal profession.

\section{Discussion and conclusions}

The propagation of South Africa's Constitution and subsequent legislation regulating the use of the country's environment by people gave explicit legislative credence to the common law public trust doctrine in environmental decision making. Notwithstanding this, in the 21 years since the promulgation of South Africa's Constitution and environmental legislation, there has been little academic and legal recognition of the public trust provisions. Against the backdrop of South Africa's biodiversity, which is, as with many other developing and developed countries, under significant threat from the impacts of land transformation and unsustainable use, the role and significance of the doctrine in decision making is questioned. Such questioning includes consideration of whether the concept has been understood or if it is awaiting rekindling to provide greater protection to South Africa's biodiversity.

Outside of the Constitution, the public trust doctrine in South African environmental law is likely to have multiple bloodlines. These bloodlines are rooted in Roman common law, recent Western ideology, African multilateral environmental agreements and international soft law. These diverse origins may have played a significant role in the variation observed in the (sometimes) contradictory coding of the doctrine in the various statutes that constitute South Africa's environmental law. It is surmised that both the drafters of the environmental statutes and the legislature adopting the same had a variable understanding of the doctrine, which, in one instance, conferred a right to the environment and in another conflated the roles of government as the trustee and the public as the beneficiaries of the trust. The relevance of this discovery is founded on two fronts. The first is that it may be inappropriate in South Africa to anchor an understanding of the public trust solely on the Western interpretations of this doctrine. The second front is a realisation that the application of the doctrine in South Africa is in its infancy. It thus stands to reason that substantial research, academic dialogue and legal argument are required for the public trust doctrine to gain prominence in South Africa's jurisprudence and biodiversity-orientated decision making.

Notwithstanding the variable manner in which it has been incorporated into the statues regulating the broader environment, the South African legislature appears to have embraced the fundamental principles of the doctrine. Of these, the policing role the public may assume and the intervention of the courts on behalf of the public are seen to be paramount for the public trust to become a powerful influence in relation to the protection and sustainable use of the country's biodiversity. Furthermore, this synergistic relationship between the government needing to make 
principled decisions and the public needing to make sound arguments to challenge decisions that fail to achieve this standard effectively extends the objective of the public trust doctrine to be supported by researchers and research institutions. In this, a reasonable expectation, if not an obligation, is placed on both the researcher and research institution, to provide accurate, robust, relevant and contextsensitive information in a form that is readily accessible by decision makers, the public and the legal profession.

Demonstrating faithfulness to the doctrine by decision makers remains a challenge. The public face a similar challenge when querying whether the official authorising the use of the environment has been faithful to their fiduciary duties to protect the public trust entity. In this respect, the degree of compliance with the public trust doctrine cannot be arbitrarily gauged, and the official requires a decision making framework or set of parameters that elucidate where the trust entity is at a significant risk of exploitation. The same applies to the public when questioning whether a decision on the use of the environment is accorded with the public trust doctrine. Here, from a biodiversity perspective, the set of nine questions presented in Blackmore (2017a) serves as a guiding framework for decision-making and evaluation. The questions not only evaluate the potential significance of the use to biodiversity but also the potential effectiveness of proposed mitigation and whether the mitigation would be effective within a foreseeable or reasonable timeframe. The application of such an approach to decisions and the evaluation of decisions taken are vital to giving effect to the public trust doctrine.

Many scholars have referred to the public trust doctrine as being a powerful tool to safeguard the natural environment, and in particular its biodiversity. In as much as the doctrine represents the ultimate safeguard against possible damage to the trust entity, its effectiveness cannot be guaranteed in all circumstances. Political, economic and social pressures that are brought to bear on government officials are persuasive, particularly in a developing and natural resource-hungry country like South Africa. Furthermore, the mere provision of the public trust doctrine in a country's environmental statute law seems to be insufficient to ensure recognition of its existence and its application in environmental decisionmaking. In view of this, it is concluded that the strength of the public trust doctrine lies in a synergistic balance between a thorough understanding of its importance by government officials, the public, researchers and the legal fraternity, and the ability of the public to hold the officials accountable, by way of appeals and judicial review, for the decisions taken.

In closing, the public trust doctrine has been explicitly included in South Africa's Constitution and environmental legalisation. Despite being in existence for over 20 years, it has enjoyed little prominence in academic discourse and judgements taken by the judiciary. The rapid loss of biodiversity in South Africa, both at a species and habitat level, highlights the need to rediscover the value of the doctrine as a means to enable both the government and the public to bring added protection to the country's natural heritage. There remains, therefore, abundant opportunity for the significance of this provision to be researched, and its application to be debated and tested at the coalface of environmental decision making and in the courts. An improved understanding of the relevance of the public trust doctrine by government officials, the general public, the legal fraternity and research institutions would promote much improved evidence-based decision making and sustainable use of the country's biodiversity.

\section{References}

Armstrong, A. \& Blackmore, A., 2017, 'Tsetse flies should remain in protected areas in KwaZulu-Natal', Koedoe 59(1), a1432. https://doi.org/10.4102/koedoe.v59i1.1432

Babcock, H., 2015, 'Is using the public trust doctrine to protect public parkland from visual pollution justifiable doctrinal creep?', Ecology Law Quarterly 42, 1-35.

Blackmore, A., 2014, 'The interplay between the public trust doctrine and biodiversity and cultural resource legislation in South Africa: The case of the Shembe Church worship site in Tembe Elephant Park in KwaZulu-Natal', Law, Environment and Development 10(1), viewed n.d., from http://www.lead-journal.org/ content/14001.pdf

Blackmore, A., 2015, 'Legal and public trust considerations for the Ndumo Game Reserve and South Africa-Mozambique border, following the migration of the Usuthu River', Journal of Southern African Public Law 30(2), 347-379. https://doi. org/10.25159/2522-6800/3585

Blackmore, A., 2017a, 'Public trust doctrine, research and responsible wildlife management in South Africa', Bothalia 47(1), a2217. https://doi.org/10.4102/abc. v47i1.2217

Blackmore, A., 2017b, 'Towards a policy for Namibia: The public trust doctrine, selective breeding, and intensive management of wildlife', African Journal of Wildlife Research 47(2) (in press). https://doi.org/10.3957/056.047.0065

Blackmore, A., 2018, 'Rediscovering the origins and inclusion of the public trust doctrine in South African environmental law', Review of European, Comparative \& International Environmental Law 27(3), http://dx.doi.org/10.1111/reel.12239

Blackmore, A.C., \& Trouwborst, A., 2018, 'Who owns and is responsible for the elephant in the room? Management plans for free-roaming elephant in South Africa', Bothalia 48(2), a2271. https://doi.org/10.4102/abc.v48i2.2271

Blumm, M. \& Guthrie, R.D., 2012, 'Internationalizing the public trust doctrine: Natural law and constitutional and statutory approaches to fulfilling the Saxion vision' UC Davis Law Review 45(1), 1-71.

Bramley, J., 2011, 'Supreme foresight: Judicial takings, regulatory takings, and the public trust doctrine', Boston College Environmental Affairs Law Review 38, 445-476.

British Parliamentary Papers, 1900, Convention for the preservation of wild animals, birds, and fish in Africa 19 May 1900, viewed n.d., from http://iea.uoregon.edu/ pages/view_treaty.php?t=1900-PreservationWildAnimalsBirdsFishAfrica.EN txt\&par=view_treaty_html

Brundtland, G.H., 1987, Our Common Future, Report of World Commission on Environment and Development, World Commission on Environment and Development at 15, Published as Annex to General Assembly document A/42/427, Development at 15, Published as Annex to General Assembly document A/42/427
Development and International Co-operation: Environment, United Nations.

Bruskotter, J., Enzler, S.A. \& Treves, A., 2011, 'Rescuing wolves from politics: Wildlife as a public trust resource', Science 333(6051), 1828-1829. https://doi.org/10.1126/ science.1207803

Clavero, M. \& García-Bertho, E., 2005, 'Invasive species are a leading cause of animal extinctions', Trends in Ecology and Evolution 20(3), 110. https://doi.org/10.1016/j. tree.2005.01.003

Cvitanovic, C., Fulton, C.J., Wilson, S.K., Van Kerkhoff, L., Cripps I.L. \& Muthiga, N., 2014, 'Utility of primary scientific literature to environmental managers: An international case study on coral-dominated marine protected areas', Ocean \& Coastal Management 102, 72-78. https://doi.org/10.1016/j.ocecoaman.2014.09.003

Dicks, L., Hodge, I., Randall, N., Scharlemann, J., Siriwardena, G., Smith, H. et al., 2014, 'A transparent process for "Evidence-Informed" policy making', Conservation Letters 7(2), 119-125.

Du Plessis, A.A., 2015, 'Climate change, public trusteeship and the tomorrows of the unborn', South African Journal on Human Rights 31(2), 269-293. https://doi.org/ 10.1080/19962126.2015.11865247

Fanelli, D., 2009, 'How many scientists fabricate and falsify research? A systematic review and meta-analysis of survey data', PLoS One 4, e5738. https://doi. org/10.1371/journal.pone.0005738

Feris, L., 2012, 'The public trust doctrine and liability for historic water pollution in South Africa', Law, Environment and Development Journal 8(1), 1-18.

Fuel Retailers, 2007, 'South Africa', Fuel Retailers Association of Southern Africa v Director-General Environmental Management, Department of Agriculture, Conservation and Environment, Mpumalanga Province, and Others 2007(6), SA 4 (CC). 
Hare, D. \& Blossey B., 2014, 'Principles of public trust thinking', Human Dimensions of Wildlife: An International Journal 19(5), 397-406. https://doi.org/10.1080/10871 209.2014.942759

IUCN, 1961, Conservation of nature and natural resources in modern African States, Report of a symposium organised by CCTA and IUCN and held under the auspices of FAO and UNESCO at Arusha, IUCN Publications new series No. 1, Arusha, Tanganyika.

Jewitt, D., Goodman, P.S., Erasmus, B.F.N., O'Connor, T.G. \& Witkowski, E.T.F., 2015, 'Systematic land-cover change in KwaZulu-Natal, South Africa: Implications for biodiversity', South African Journal of Science 111(9/10), Art. \#2015-0019, 1-9. https://doi.org/10.17159/sajs.2015/20150019

Johnson, S. \& Graber B., 2002, 'Enlisting the social sciences in decisions about dam removal: The application of social science concepts and principles to public decision-making about whether to keep or remove dams may help achieve outcomes leading to sustainable ecosystems and other goals in the public interest', AIBS Bulletin 52(8), 731-738. https://doi.org/10.1641/0006-3568(2002) 052[0731:ETSSID]2.0.CO;2

Krausman, P. \& James, C. III (eds.), 2013, Wildlife management and conservation: Contemporary principles and practices, John Hopkins University Press, Baltimore, MD.

Kundis-Craig, R., 2010, 'Adapting to climate change: The potential role of state common-law public trust doctrines', Vermont Law Review 34(781), 831-841.

McShane, T., Hirsch, P.D., Trung, T.C., Songorwa, A.N., Kinzig, A., Monteferri, B. et al. 2011, 'Hard choices: Making trade-offs between biodiversity conservation and human well-being', Biological Conservation 144(3), 966-972. https://doi. org/10.1016/j.biocon.2010.04.038

Mehta, 1997, India, M.C. Mehta v Kamal Nath (1997) 1 SCC 388.

Minister of Water and Environmental Affairs, South Africa, 2016, Minister of Water and Environmental Affairs and Another v Really Useful Investments No 219 (Pty) Ltd and Another (436/2015) [2016] ZASCA 156.

Muir, A., 2016, 'Of fences, game and property - Some unresolved issues of ownership of wild animals in South Africa', Stellenbosch Law Review 27(1), 136-160.

Myhr, I.A. \& Traavik, T., 2002, 'The precautionary principle: Scientific uncertainty and omitted research in the context of GMO use and release', Journal of Agricultural and Environmental Ethics 15(1), 73-86. https://doi.org/10.1023/A:1013814108502

Nguyen, V., Young, N. \& Cooke, S., 2017, 'A roadmap for knowledge exchange and mobilization research in conservation and natural resource management', Conservation Biology 31(4). https://doi.org/10.1111/cobi.12857

Niaz, 1996, Kenya, Niaz Mohamed Jan Mohamed $v$ Commissioner for Lands \& 4 others (eKLR 1996).

Novacek, M. \& Cleland, E., 2001, 'The current biodiversity extinction event: Scenarios for mitigation and recovery', Proceedings of the National Academy of Sciences 98(10), 5466-5470. https://doi.org/10.1073/pnas.091093698

Pullin, A.S. \& Knight T., 2003, 'Support for decision making in conservation practice: An evidence-based approach', Journal for Nature Conservation 11, 83-90. https:// doi.org/10.1078/1617-1381-00040

Sagarin, R. \& Turnipseed, M., 2012, 'The public trust doctrine: Where ecology meets natural resources management', Annual Review of Environment and Resources 37 1-496. https://doi.org/10.1146/annurev-environ-031411-165249
Sand, P., 2014, 'The concept of Public Trusteeship in the transboundary governance of biodiversity', in L.J. Kotze \& T. Marauhn (eds.), Transboundary Governance of Biodiversity, Brill Nijhoff, Leiden.

Sarewitz, D., 2004, 'How science makes environmental controversies worse by E. Löbrand, and G. Öberg', Environmental Science and Policy 7(5), 385-403. https://doi.org/10.1016/j.envsci.2004.06.001

Sax, J., 1970, 'The public trust doctrine in natural resources law: Effective judicial intervention', Michigan Law Review 68(3), 471-566. https://doi.org/10.2307/ 1287556

Sax, J., 1971, Defending the environment: A strategy for citizen action, Alfred A Knopf, New York, p. 165.

Singh, G., Tam, J., Sisk, T.D., Klain, S.C., Mach, M.E., Martone R.G. et al., 2014 'A more social science: Barriers and incentives for scientists engaging in policy', Frontiers in Ecology and the Environment 12, 161-166. https://doi.org/ $10.1890 / 130011$

South Africa, Constitution of the Republic of South Africa 1996

South Africa, Integrated Coastal Management Act 24 of 2008.

South Africa, National Environmental Management: Biodiversity Act 10 of 2004.

South Africa, National Environmental Management: Protected Areas Act 57 of 2003.

South Africa, National Heritage Resources Act 25 of 1999.

South Africa, National Water Act 36 of 1998.

South Africa, White Paper on Environmental Management Policy for South Africa, Government Notice 749, Government Gazette 18894 of 15 May 1998.

South Africa, White Paper on the conservation and sustainable use of South Africa's biodiversity (1997), Published in GN 1095 GG No. 18163, dated 28 July 1997.

Takacs, D., 2008, 'The public trust doctrine, environmental human rights, and the future of private property', New York University Environmental Law Journal 16, 711-766.

Torres, G. \& Bellinger, N., 2014, The public trust: The law's DNA, Cornell Law Faculty Publications, Paper 1213, viewed n.d., from http://scholarship.law.cornell.edu/ facpub/1213

Treves, A., Chapron, G., López-Bao, J.V., Shoemaker, C., Goeckner A.R. \& Bruskotter J.T. 2017, 'Predators and the public trust', Biological Reviews 92(1), 248-270. https:// doi.org/10.1111/brv.12227

Turnipseed, J., Berkman, M., Blumm, M., Crowder, L., Currie, D., Gjerde, K. et al., 2012, The public trust doctrine and Rio+20, viewed 20 June 2017, from http://www3.ejoussour.net/files/The $\% 2$ Public $\% 20$ Trust $\% 20$ Doctrine $\% 20$ and $\% 20$ Rio $\% 20$ joussour.n

Van der Schyff, E., 2013, 'Stewardship doctrines of public trust: Has the eagle of public trust landed on South African soil?', South African Law Journal 130(2), public trust

Van Noorden, R., 2011, 'The trouble with retractions', Nature 478(7367), viewed n.d., from http://www.nature.com/news/2011/111005/full/478026a.html

Wood, M., 2013, Nature's Trust: Environmental Law for a New Ecological Age, Cambridge University Press, Cambridge. 